\title{
Kathryn Findlay:
}

\section{Fionn Stevenson}

Field noun: An area of open land, especially one planted with crops or pasture, typically bounded by hedges or fences. verb: A particular branch of study or sphere of activity or interest.

Fieldwork noun: Practical work conducted by a researcher in the natural environment, rather than in a laboratory or office. (Oxford English Dictionary).

Kathryn Findlay's untimely death has left us bereft not only of one of the world's most poetic architects of recent times but also a beacon of research-led practice as conducted through her 'fieldwork'. That these two descriptions can sit side-by-side is testament to the extraordinary capacity she had for continually unearthing new ideas from her fertile imagination and always testing and grounding them through disciplined and rigorous inquiry. Her 'field' began in the rugged glacier scoured hills of her birthplace on 26 January 1953, in Finavon on the east side of Scotland, where she was raised as a sheep farmer's daughter. Her approach to architecture as 'movement through landscape' was the green fuse that renewed itself in each of her projects - deeply informed by the very stuff of nature from which she herself was formed.

\section{AA and theory}

Having first studied fine art at Edinburgh College of Art, Findlay moved to England at the end of her first year in 1972 to study at the Architectural Association. Here she was tutored by Peter Cook, Christine Hawley, and perhaps more importantly by Leon van Schaik. He first inspired her with the idea of space as a solid matter that could be carved-out and sculpted from within and also introduced her to The Poetics

\section{3-2014}

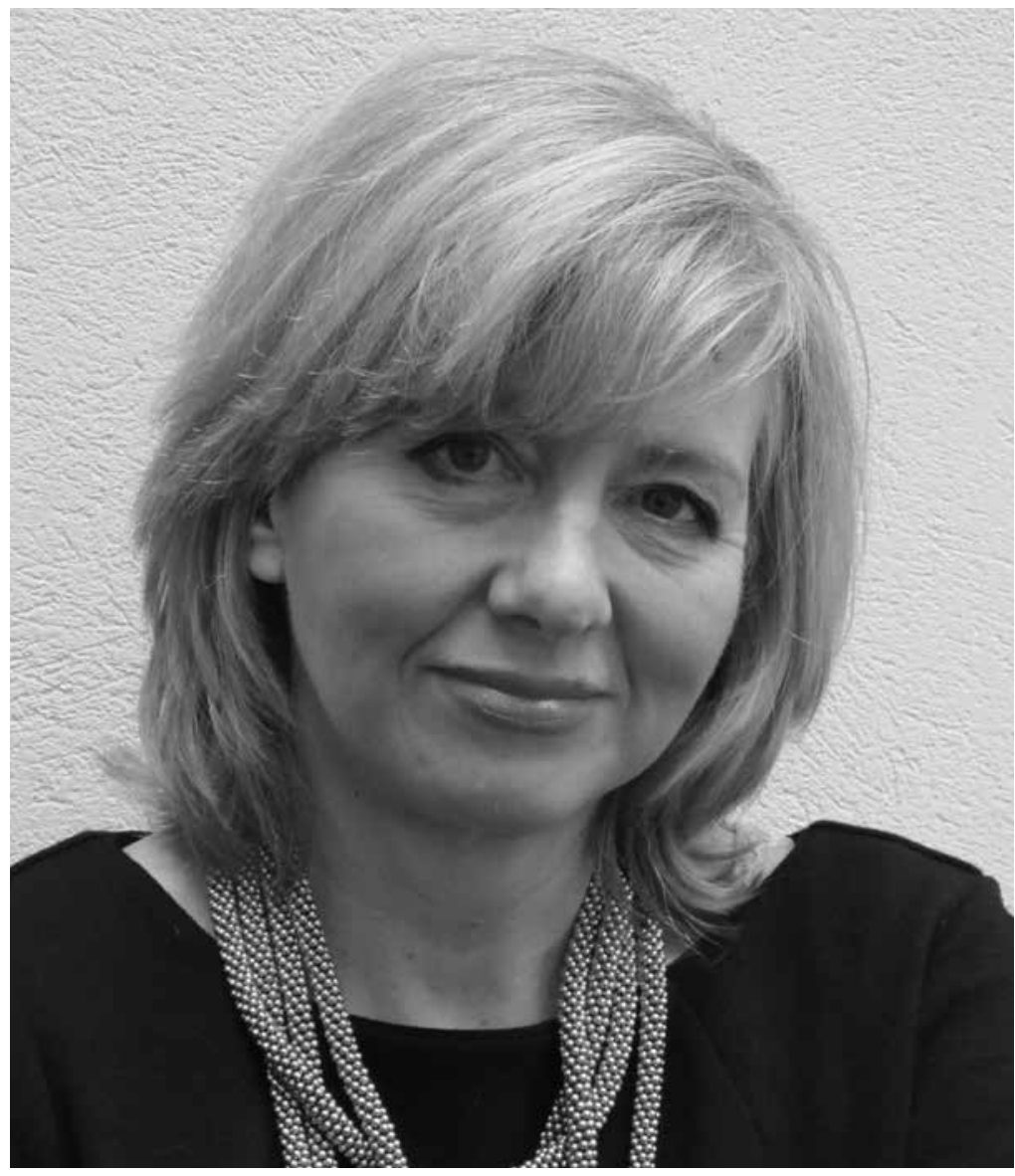

1 Kathryn Findlay, a beacon of research-led practice conducted through her 'fieldwork'

of Space by Gaston Bachelard. Another AA tutor of major influence was Ranulph Glanville, who introduced her to systems theory, cybernetic thinking and the Radical Constructivism which was fashionable at that time. Her understanding of these theories later gave Kathryn a direct means of articulating her ecological approach to design:

[...] rather than reinforce the shells that protect us, we must think of ourselves as open systems, taking in information from the outside while venturing outside ourselves - always in the interest of selfreform.

The design approach that she developed over time, together with her husband in the Ushida Findlay Partnership, was summed up in 1994 as three threads of spatial exploration: first, spatial topology emerging from the morphology of action; second, constructed ephemerality creating perspective experience; third, geometry distilled from natural structures. ${ }^{2}$ 


\section{Japan and practice}

In 1979, having been inspired by Japanese architecture and culture as a student, Findlay headed to Tokyo, ostensibly with a oneway ticket. She worked in Arata Isozaki's office, where she met her future Japanese husband Eisaku Ushida. She was amazed to discover that he too had worked
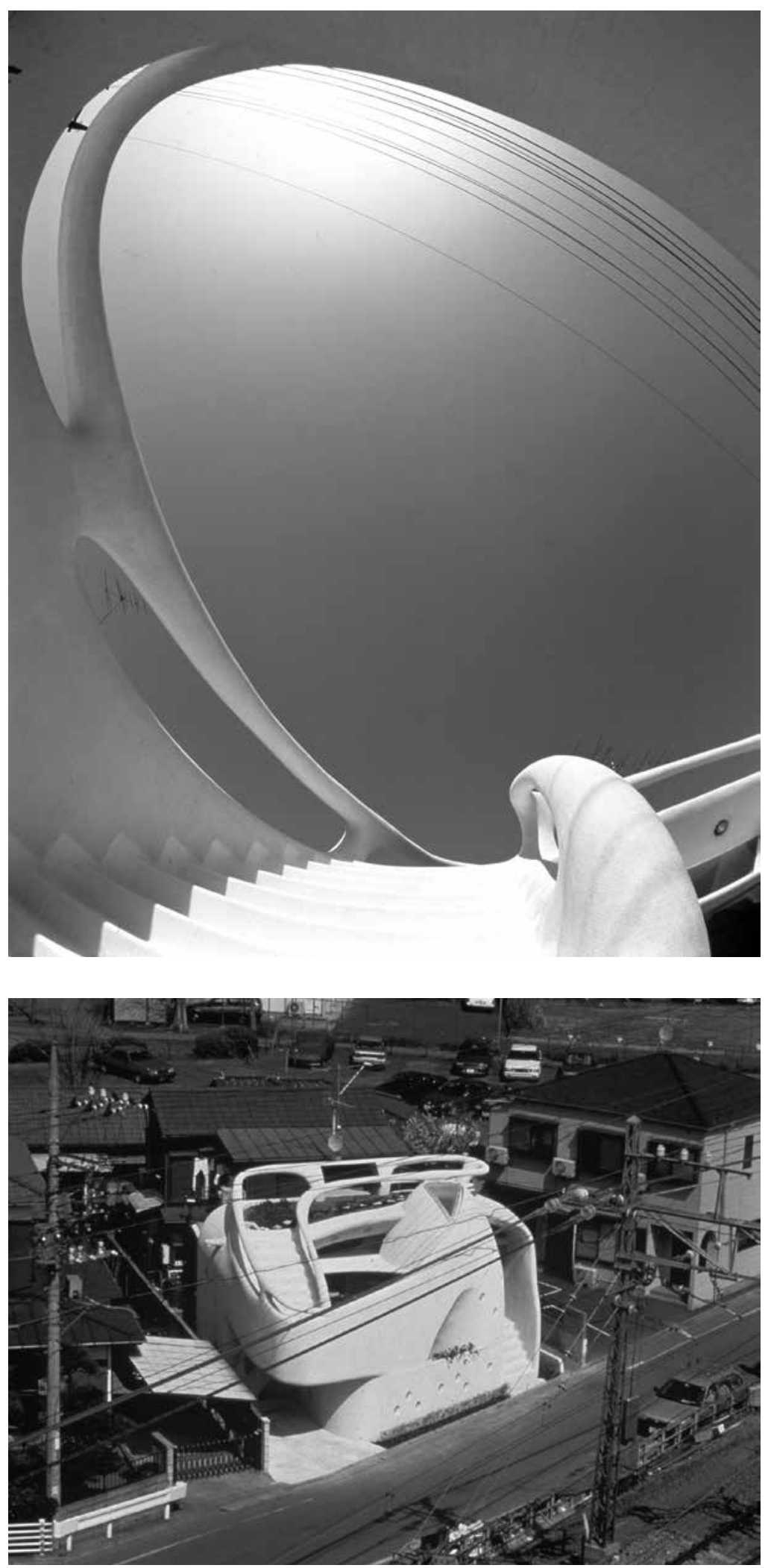

2a,b Truss Wall House, interior and exterior with Bachelard's poetics in his own thesis on the Josephine Baker House by Adolf Loos and that they had a major coincidence of interests in their approach to practice related to Loos's Raumplan - his contiguous approach to space - and his dual celebration of natural and artificial materiality [1]. Kathryn would later cite Villa
Müller: A Work of Adolf Loos as her favourite architectural book. ${ }^{3}$ The Ushida Findlay Partnership was set up in 1986 and the married couple quickly made their mark with three remarkable houses which transformed architectural thinking: the Echo Chamber (their first commission in 1988 , the result of a competition), Truss Wall House (completed in 1993) and The Soft and Hairy House (also completed in 1994). The practice was viewed as an alchemical fusion of Findlay's wild imagination and Ushida's technological prowess.

Each house pushed a new boundary, with the Truss Wall House technology of reinforcedconcrete compound curves defined by $20 \mathrm{~cm}$ vertical section slices predating computational ${ }_{3} \mathrm{D}$ digital moulding that is so ubiquitous today [2a,b]. Ushida Findlay's sublime use of fractal geometry and intense preoccupation with fine detailing was developed through their bespoke technique of 'slimy drawing': a painstaking process of layering beautifully handcrafted axonometric drawings to form an 'x-ray' through each of their buildings. At the same time, Findlay was deeply engaged in exploring the materiality of architecture, physically testing with her bare hands new forms of construction such as filling balloons with liquid mortar in the Truss Wall House. What differentiates this approach to architecture, as processrelated form rather than mere biomorphic preoccupation, is set forth in their manifesto 'Matrix 1996':

Our interest is based not on the forms themselves, but the relations between the parts and the whole, and in the relations they describe. The lesson we draw from the discoveries of fractal geometry is that it requires a humble observation of the natural world. Geometry abstracted from natural or social phenomena contains the self-structuring capacity of its source. That is the excitement. 'Field' for us is the ground: the natural, social and topographical site of all architectural activity. ${ }^{4}$ This is clearly expressed in the Truss Wall House as both an organic sculpture and a home with an infinite variety of shapes and forms which, echoing Loos's Raumplan diktat, defy the need for separately articulated floors, revealing instead a continuously flowing natural landscape in all dimensions. 


\section{Returning 'home'}

After a successful career in Japan,

Kathryn eventually returned back to London and set up her own practice in 2001, having split up from her husband. She built on the fabulous 'Poolhouse 1' project (completed in 2001) [3] with an equally 'futurerustic' thatched-roof-perchedon-glass approach to 'Poolhouse 2' (2009) as well producing an astonishing RIBA competitionwinning entry to 'reinterpret the country house' rebuilding Grafton New Hall, a country house in Cheshire, as a four-winged starfish designed to mimic the sun's route across the sky. Despite acceptance by the planners and paving the way for future non-traditional country houses, this project was eventually built, not in England, but in Doha, as a royal villa for the wife of the Qatari Emir. This was not enough to save the practice from bankruptcy in 2004 due to a major project falling through at the last moment and not enough cash flow from new projects. As ever, Findlay bravely picked herself up and started all over again, this time employed by the School of Architecture at the University of Dundee, eventually to become their Professor of Architecture and Environment in 2006.

Coming 'home' for Findlay was a continuing act of translation, with the migrant's piercing view of her own precious country thrown even more sharply into relief as she launched herself into a new project - bringing her research and design approach back to life through a direct collaboration between academia and practice.

\section{Research-led teaching}

Kathryn had spent twenty years teaching and working in Japan, appointed as the first female academic in the Department of Architecture at Tokyo University and the first foreigner to teach there since the nineteenth-century Meiji period. She fearlessly encouraged her students to engage with her own radical approaches to researching and testing design strategies in the face of initial bewilderment from certain Japanese professors and then their final grudging admiration for her unorthodox methods. She had no time for the then-fashionable Japanese Minimalism or the 'static and repetitive' architecture of Tadao Ando. The strength it took as a woman to work in such a male-dominated society, and to defy convention, cannot be underestimated.
After she arrived at Dundee, Findlay set up a unique studio/ office in the School called 'Field' - a design research laboratory which aimed to explore and expand on ideas developed from its commercial arm, 'Fieldwork', in turn, linked to her existing practice. For a few, brief, heady years those students and staff who were open to her experimental approach were exposed to some of the most fertile and abundant creativity going of any school of architecture at the time. Findlay was challenging us not only to re-engage with the land through the production of food - a theme which built on her 'House Prototype 1 ' from ten years earlier
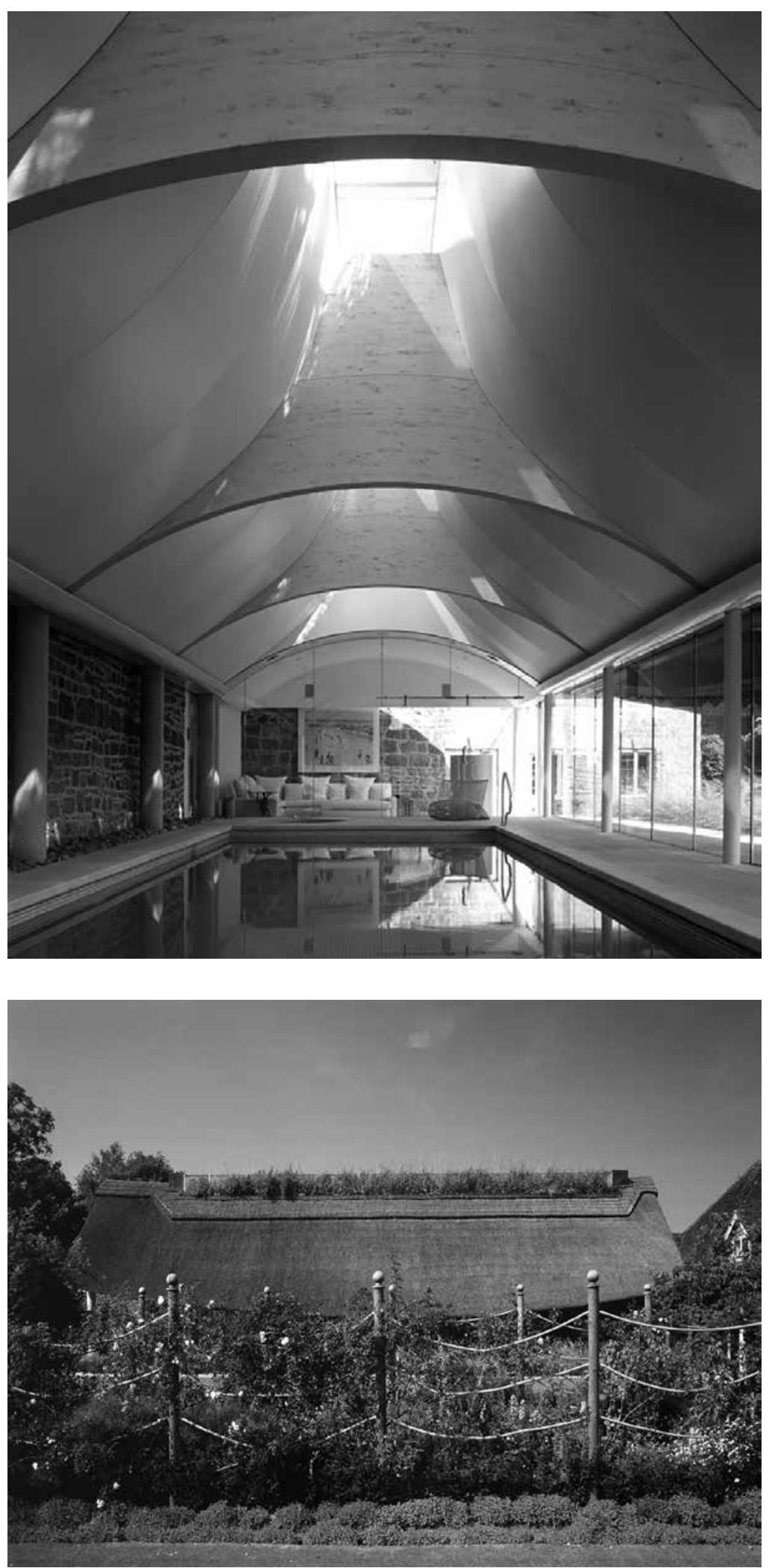

3a,b Poolhouse 1, interior and exterior 


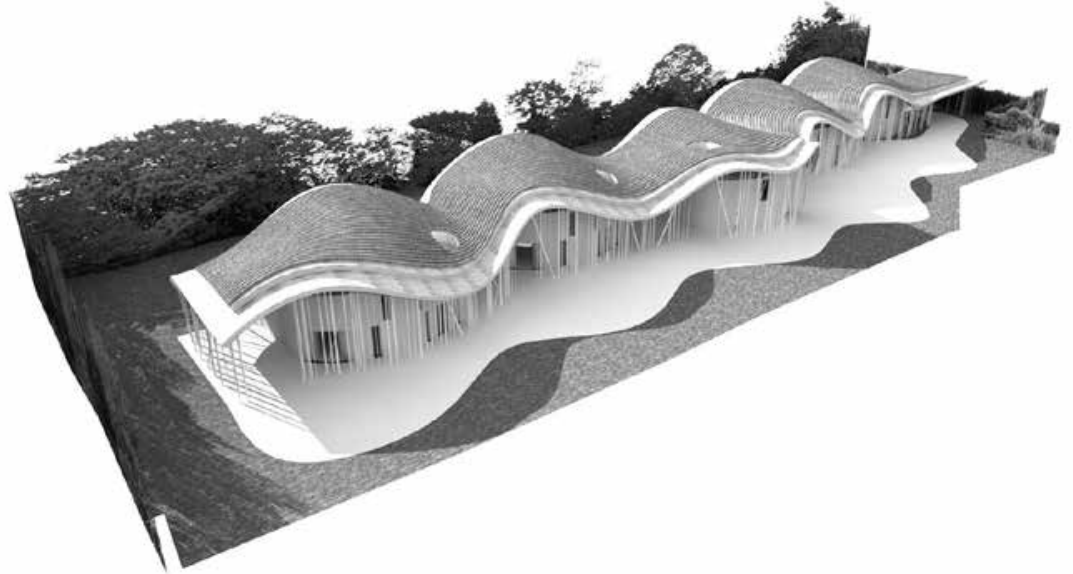

4 Park House

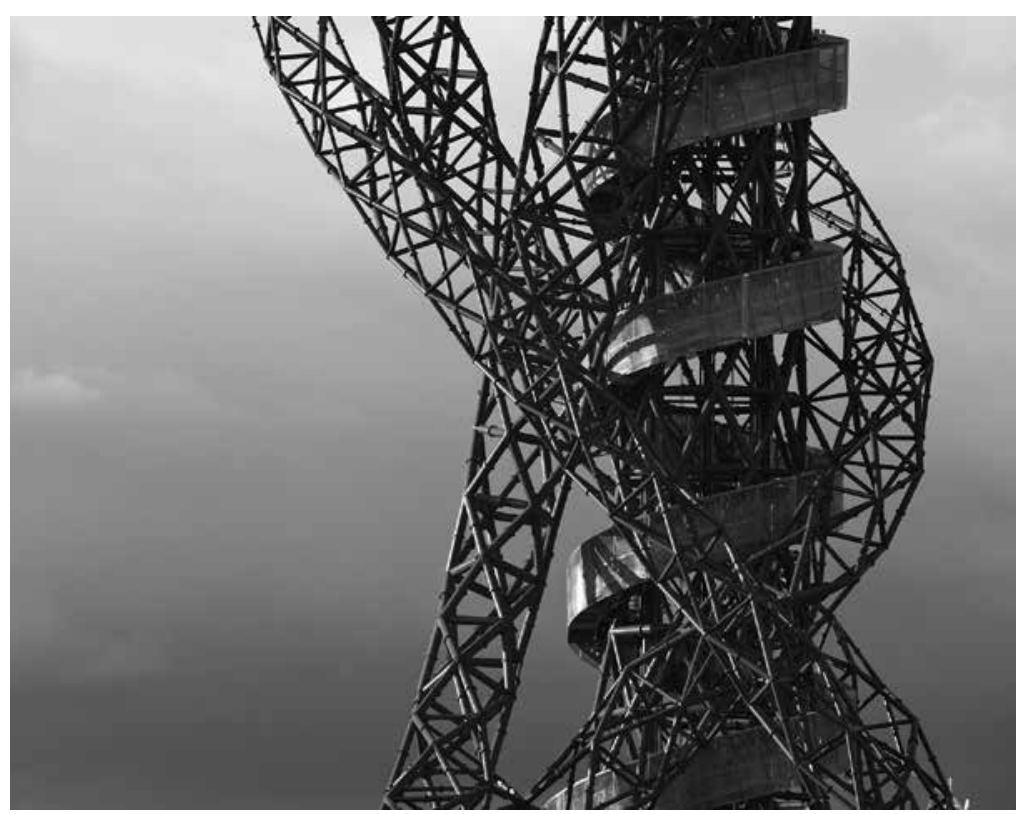

5 ArcelorMittal Orbit Tower, London 2012 Olympics

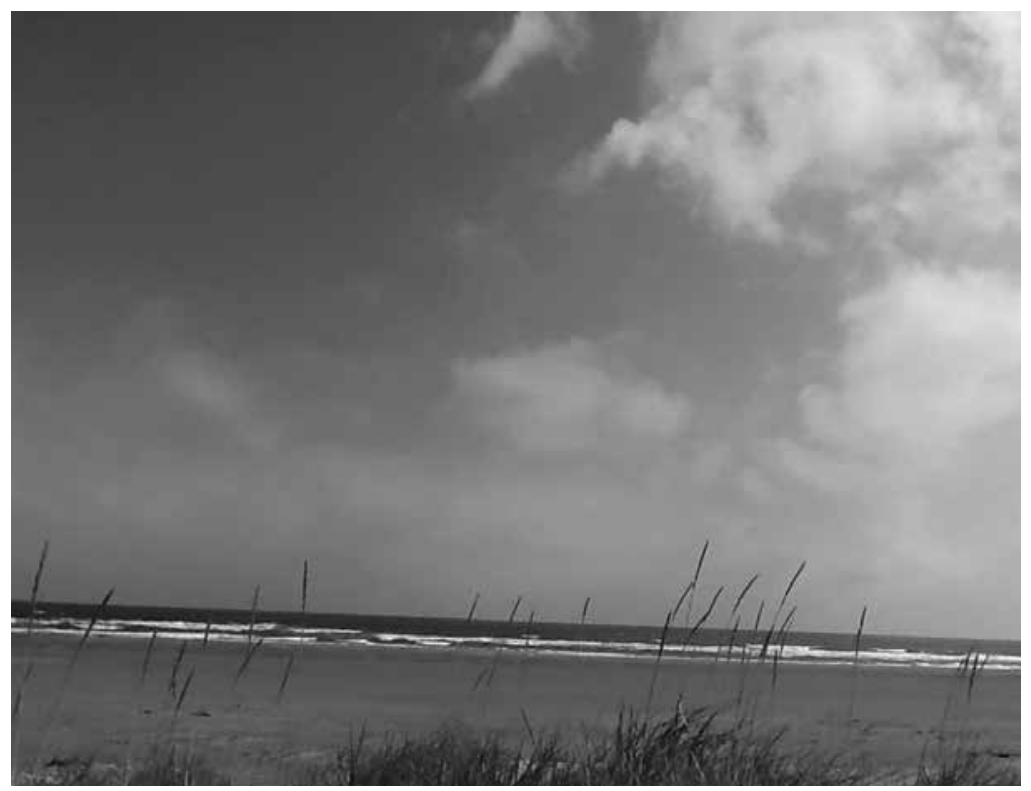

6 Tentsmuir Beach with its rooftop vegetable garden decades ahead of its time - but to consider the entire production of place through a systemic enquiry of the most rigorous kind. Projects ranged from the conception of a thirty-mile-wide land museum for an AHRC research bid, through to the hugely entertaining but deadly serious 'Hill' public building for sensory experience opposite the GLA building in London, to Park House, a group of five separate homes under one green roof [4], and an unbuilt proposal for the V\&A at Dundee. The marriage of unequals did not last, and Findlay left the University of Dundee in 2009 to start her practice afresh, leaving an unfinished legacy of research-led teaching.

In the end, after a final burst of creativity with Anish Kapoor, realising the hugely successful ArcelorMittal Orbit tower for the London Olympic Park in 2012 [5], Findlay returned to her beloved Tentsmuir Forest in Fife with its self-perpetuating Scots and Corsican pine trees $[6]$, across the river from Dundee, one last time before rapidly succumbing to a brain tumour on 10 January 2014. For her, these gentle but resilient trees symbolised the future and a way forward for our troubled planet and its architecture. On her wicker coffin in London lay a bouquet of gentle, delicate and vulnerable roses interwoven with feisty Scottish thistles and wild, out-there moorland heather. What better epitaph for this fine quine, choosing beauty to the very last. She is survived by her two children, Miya and Hugo Ushida, as well as by her sister Alison and brother Alan.

FIONN STEVENSON

Fionn Stevenson is Head of School and Co-Director of the Centre of Excellence in Sustainable Building Design at the University of Sheffield School of Architecture

\section{Notes}

1. Leon van Schaik (ed.), Ushida Findlay, 2G International Architecture Review No. 6 (Barcelona: Gustavo Gili, 1999).

2. Ibid.

3. L. Van Duzer and K. Kleinman, Villa Muller: A Work of Adolf Loos (New York: Princeton Architectural Press, 1994).

4. Van Schaik (ed.), Ushida Findlay.

\section{Illustration Credits}

arq gratefully acknowledges: Ushida Findlay/Kathryn Findlay Architects, courtesy of Miya Ushida, all images 